been recorded seems to have a cause peculiar to itself. This may be either connected with mating or it may have nothing to do with it, as seems to be the case with the form described as occurring about the university campus. As a possible explanation of the movement in the present case, it may be offered that it is a preparation for winter. The adults live over the winter under logs, leaves, etc. Their eggs are laid in low, damp areas. Such localities are unfit for hibernation, and hence the migration to more dry and protected localities.

Department of Zoology, Ohio State Univers.tTy.

\section{RECENT ZOOPALEONTOLOGY.}

STEGOCERAS AND STEREOCEPHALUS.

This review of the above-named genera of dinosaurs, by the able paleontologist Franz Baron Nopcsa (Centralblatt für Mineralogie, etc., 1903, No. 8), is a highly important one and is, at the same time, suggestive of our limited knowledge of the Dinosauria generally and of the great results to be looked for from the study of this group of reptiles in the future. These animals were recently described by the writer from the Belly River formation of the Red Deer River region. One has a solid horn in the front part of the skull, the other a solidly plated head.

Nopcsa's interpretation of the Stegoceras skull elements is noteworthy and accentuates the necessity of having more material for study before definite or final determinations can be made. He comes to the conclusion that the Stegoceras specimens that were supposed to be from ' the median line of the head in advance of the nasals'* are to be interpreted rather as representing the frontal and nasal elements of the skull.

In support of this decision attention is called to the frontal of Camptosaurus prestwichi, as figured by Hulke in the Quarterly Journal of the Geological Society for 1880. ' In this figure the strong, general structural resemblance to the Stegoceras

* Geological Survey of Canada. Contributions to Canadian Palæontology, Vol. III. (quarto), pt. II., p. 69, pl. xxi, figs. 1-5. specimens, particularly noticeable on the under surface, is pointed out with emphasis. Reference is also made to a similarly shaped, but as yet undescribed, frontal of Mochlodon.

According to the above interpretation, Stegoceras brings to our notice an entirely new type-a unicorn dinosaur, of especial interest in that heretofore a form having an unpaired horn springing from the frontonasal region was unknown.

It is still considered problematical whether Stegoceras should be assigned to the Ceratopsidæ or to the Stegosauridæ.

Stereocephalus, the second genus, is referred by Nopcsa to the Acanthopholididæ, and is regarded as a new and important type capable of throwing additional light on the modification of the skull of the Ceratopsidæ.

It is hoped that further contributions to our knowledge of the Cretaceous dinosaurs may be forthcoming from the pen of this sympathetic writer and gifted observer.

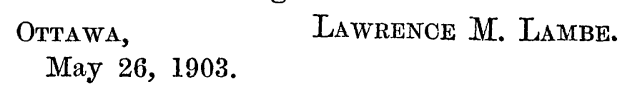

\section{SCIENTIFIC NOTES AND NEWS.}

THE remaining separata of the late Professor Edward D. Cope have been arranged in sets and are ready for free distribution to students and institutions willing to pay express charges on them. Application should be made to Mrs. E. D. Cope, Haverford, Pa.

Wesleyan UnIversity has conferred its LL.D. on William D. Brewer, professor emeritus in the Sheffield Scientific School of Yale University.

THE ex-resident physicians and associate physicians of Johns Hopkins Hospital gave a dinner on May 15, at the Maryland Club, Baltimore, in honor of Dr. William Osler, at which he was presented with a copy of the 'Dictionary of National Biography.'

The Zoological Society of London has confirmed the action of the council in granting a pension of $£ 700$ to Dr. P. L. Sclater, F.R.S., in consideration of his services to the society for forty-three years.

President W. G. Tight, of the University of. New Mexico, is with the Annie S. Peck 